\title{
アラビアン・ナイト研究の問題と展望
}

\section{The Arabian Nights Studies: Current Scene}

\section{西尾哲夫龹 NisHio Tetsuo}

\section{I. 「イフタフヤーシムシム」}

本稿の目的は, アラビアン・ナイト研究の案内書として最近出版された Robert Irwin, The Arabian Nights: A Companion. (London: Allen Lane/The Penguin Press, 1994. 344pp. ISBN 0-713-99105-4 Hardcover, £ 20.00) の批評を通して, これまでのアラビアン・ナイト研究の問題と今後の展望について考察することである。 あわせて，最近完訳なった前嶋・池田訳『アラビアン・ナイト』の文明史的意味につい (1) ても考察してみたい。

リチャード・バートンによれば，アラビアン・ナイトを全部読もらとした者は必ず途 中で死んでしまらといら俗信がアラブ世界にはあるらしいが，読むだけでも大変なアラ ビアン・ナイトのアラビア語原典からの全訳を志した故前嶋信次氏，そしてその訳業を 完成させた池田修氏による『アラビアン・ナイト』（平凡社，東洋文庫所収）は，日本 の翻訳文化の一つの偉業と言える。前嶋氏が『アラビアンナイトの世界』（講談社現代 新書) で述べ，また池田氏が記念講演で述べたように，アラビアン・ナイトは未だに多 くの謎に満ちた存在であり, 文学としての読まれ方以上に, 「語り」の型に鋳れられた 民衆の意識を読み解く作業が切望される。

Introduction で著者は執筆の動機と目的について述べる。アラビアン・ナイトは，ギ ボンの『ローマ帝国衰亡史』やプルーストの『失われた時を求めて』と同様, 誰もが知 っていながら実際に全部読んだ者は殆どいない長編だが，19世紀ヨーロッパの読書人の 書架を飾ったバートンの翻訳も，今ではアラジン，アリババ，シンドバッド等の一部の 物語，とれも子供向けに不道徳な部分を削除した形でしか，文学的余命を保っておらず， グリム童話に類するものにしか見られないのはなぜだろらか。アラビアン・ナイトは西 洋で書かれたアラブ文学史であまり丁重な扱いを受けてこなかったし，それ以上にアラ ブ世界の特に知識人にとって「文学」の名に值するものともみなされてこなかったのは， なぜだろうか。本書の目的は, 文学的理解の「手引書」として, アラブ世界の文学的伝

東京外国語大学アジア・アフリカ言語文化研究所助教授

Associate Professor, ILCAA, Tokyo University of Foreign Studies 
統に関する背景的情報を提供することであり，さらに各物語が当時どんな目的で作られ， どのように語られたり聴かれたりしたのか，ヨーロッパやアメリカではどのように受容 されたのかについて探ることである。本書はアラビアン・ナイトを社会史の資料として 理解するための「手引書」ですある。社会とその人々の「心性 (mentalité)」を探る一 環として，本書はアラビアン・ナイト研究の歴史そのものをも考察の対象とする。たた し，アラビアン・ナイトと絵画・音楽といったテーマは扱われない。では，「イフタフ ヤーシムシム」のごまの呪文とともに本書の扉を開けてみよう。

\section{II. 異端の翻訳者}

第 1 章 Beautiful Infidels〔美しき異端者達〕では，時代の嗜好にあらといら意味で 上品な翻訳の方を厳密な翻訳よりも優先させたルネッサンス期の古典翻訳家を本来指す 章題からも判るよらに, アラビアン・ナイトの翻訳に関わる問題が扱われる。まず，ア ラビア語の難しさ, 特にアラビアン・ナイトが書かれた中世アラビア語といら口語表現 を多く含えだ言葉の翻訳に伴ら難しさについて触れた後に，アラビアン・ナイトの翻訳 に固有の障害を三つ挙げている。第一に圧倒的な量であり，第二に本来口頭で語られる べきものであることによる文体的重々しさであり，そして最後に最も重要なことだが， アラビア語原典の決定版がないことである。アラビア語版には主なものとしてカルカッ タ第一版と第二版，ブーラーク版，ブレスラウ版，マフディー版があるが，完本でない マフディー版を除いて学問的に厳密な文献批判と校訂作業によって出版されたアラビア 語版はなく，どの版も多かれ少なかれ「ちんぷんかんぷん」な文章を含んでいる。どこ まで翻訳者の改訂が許容されるかという翻訳一般の問題とも関連するが，アラビアン・ ナイトの翻訳に执いては，いかなる翻訳も改訂を行わざるを得ず，著者の言葉を借りれ ば，「良い翻訳とは必ずしも意味の良くわかる翻訳とは限らない」。

しかし，「良い翻訳」の意味する内容が時代の風潮に影響されてきたのも事実である。 アラビアン・ナイトの翻訳史は，その圧倒的な量を恐れることなく，自らの嗜好と理想 のままに訳し方を選び，さらには原典さえも改竄する訳者達の類まれな個性と時代の精 神が織り成す文明史的事件なのである。アラビアン・ナイトを「発見」し，初めてヨー ロッパに紹介したガラン, 訳書も底本の写本も失われ重訳版しか残っていないハンマー プルグシニタル, 底本となった写本の由来が疑わしいハビヒト, 語学的に正確で百科全 書的注釈が豊かだが少なからず恣意的に取捨選択を行ったレイン，アラビアン・ナイト を何よりも文学としてとらえ翻訳困難な詩や好色な部分も厭わず訳したペイン，との常 軌を逸した生き方に似てその翻訳も裠貶はげしいバートン, 当代の文学者達の熱烈な支 持を受けたが，偏見と曲解に満ら，語学力も疑わしいマルドリュス，そのマルドリュス 
の翻訳を絶賛し，英訳を引き受けながらも果たせなかったアラビアのロレンスこと T . E.ロレンス等，まさしく訳者自身が社会の「異端者」の如くである。

このような翻訳の歷史とヨーロッパ文学への影響を見る時, アントワーヌ・ガランこ そが「アラビアン・ナイトの真の著者である」といら著者のやや逆説的な指摘はあなが ち誇張ではない。また「ガランは子供に，レインは図書館に，バートンはどぶに」と当 時酷評されたバートン訳こそが, 翻訳自体の総合点の高さと, 訳書自体が後の文学や文 化に与えた影響の大きさの点で判断するならば, 最も傑出した存在であると言わざるを 得ない。その意味で, 英文学はアラビアン・ナイトとの交流によって新たな文化を創出 したのであり, 著者が指摘するように, 現在最も正確なヨーロッパ語訳の一つであるェ ンノ・リットマンのドイッ語訳は，「噓のつけないワシントン」の如く，ドイッ的誠実 さの見本ではあっても，ドイッ文学・文化に影響を与えることはなかったのである。

しかしながら，世界文学としてのアラビアン・ナイト・エンターテインメントは， ヨ 一ロッパ・キリスト教世界がオリエントとしてのアラブ・イスラム世界を科学的に理解 しょらといら19世紀の文化的土壤の中から産まれたのであり，情報過多の時代に拈ける 学問的に完全なアラビアン・ナイトの翻訳といらものは, 古典の正確な紹介といら以上 の文明史的意味を持てないのではないだろらか。リットマン訳に対する著者の評価は そのまま『東洋文庫』といら古典シリーズに収まった前嶋・池田訳『アラビアン・ナイ ト』の評価でもある。日本人のアラブ世界理解に貢献するものであっても，19世紀のヨ ーロッパで見られたよらな影響を日本文化に与えることはもはやありえないのではない だろらか。

\section{III. 原典の迷宮}

第 2 章 The Book without Authors [作者なき書物】では, アラビア語原典の成 立に関する問題が扱われる。アラビアン・ナイトの内容に関する従来の研究は, 本来の アラビアン・ナイトがいかなる姿をしていたかについての十分な文献批判に基づくもの ではなく，その議論は時として不毛になりがちであった。しかしながら，語られる物語 の登場人物さながらに金銭欲と名誉欲にとらわれた偽造者が活躍するアラビアン・ナイ 卜原典の写本発見の歴史物語は，まるでアラビアン・ナイトが語る，迷路のよらな中世 イスラム都市にある迷宮に迷い込むようなものである。

18世紀初頭のガラン訳によって初めてアラビアン・ナイトはヨーロッパの知るところ となったわけたが，最初のアラビア語版を印刷したのもヨーロッパの東洋への深い関心 のなせるわざであった。最初の印刷本であるカルカッタ第一版は最初の二百夜のみで, 写本情報もなく, 本来語学教材用であった。次に印刷されたのは, いわゆるブレスラウ 
版である。これは八ビヒトが翻訳の底本にしたと主張するチュニジア写本を基に校訂さ れたものである。しかしながら，マクドナルドの研究によれば，元来八ビヒトの主張す る写本など存在せず，彼の訳は様々なテキストの訳の寄せ集めであり，同様にブレスラ ウ版も複数の写本の寄せ集めにすざない。アラブ世界の本格的印刷の始まりであるブー ラーク印刷所で印刷されたのが，いわゆるブーラーク版である。この版は言語面でも内 容面でも整合性が高く，実在する一写本から校訂されたものだが，残念ながら写本情報 はなく，同写本す失われてしまったらしい。そして，ブーラーク版も含めたそれまでの 印刷本と18世紀のエジプト伝来写本から，現在最も信頼の怙ける完本とされるいわゆる カルカッタ第二版を出版したのが，マックナーテンであり，1839-42年のことであった。 前嶋・池田訳を含めてバートンやリットマンといった訳がこの版を底本としている。し かしながら, 後に触れるように, カルカッタ第二版も学問的に十分な校訂作業の産物で はなく,アラビアン・ナイトの写本自体の性格とも関連して決定版とは言い難い。

信頼にたる原典作成を目的として現存する写本の綿密な研究をしたのが，バートン訳 飞協力したパリ国立図書館の司書, ゾータンベール[ツォーテンベルグ〕である。現在 少なくとも22の写本が確認されているが, その殆どが彼によって研究され, その中の多 くがェジプト伝来であり, 他にシリア伝来が数写本, イラク伝来が一つあることが判明 した。エジプト版の大部分は, 近代になってヨーロッパ人の収集家の好みにあらように 書き直されたものであり, 当時の印刷流布本の影響があることも判った。彼の最大の功 績は, ガランが使用したがその後失われていた写本を発見したこと, イラクの古い伝承 による最も原書の形に近いバグダード版を同定したこと，さらにそのバグダード版の中 に，従来の印刷本や再発見されたガランの写本にも含まれておらず，ガランの創作では ないかと疑われていたアラジンの物語を発見したことである。しかしながら，ガランの 利用した写本は他にもいくつかあったようであり, エジプト版より本来のアラビアン・ ナイトに近いと考兄られたガラン版の底本であるシリア版の復元のための校訂作業に着 手したのが，ダンカン・ブラック・マクドナルドである。その目的は彼自身の手では成 就されなかったけれども，アラジンと同様にガランの創作と疑われていたアリ・ババの 物語の写本をオックスフォードの図書館で発見したことと, 先述したようにブレスラウ 版の由来を見破ったことは，彼の最大の功績である。

そして，アラビアン・ナイト研究史上画期的な仕事をしたのが，マクドナルドのガラ ン版シリア原典作成のプロジェクトを引き継ぎ, 初めて学問的に信頼の拉けるシリア版 原典を出版したムフシン・マフディーである。マフディー版に関する詳しい議論は本書 に譲るが，本来の原文が様々なスタイルのアラビア語から成り立っていたこと，従来の 版とは異なり本来のアラビアン・ナイトには物語の全体的テーマに何らかの一貫性があ 
ったことが，彼によって判明した。また，その25年にもわたる詳細な文献学的研究の副 産物として，イラクの古い伝承によるものとして重視されていたバグダード写本が，レ バノン人ミカェル・サッバーグの名誉欲と金銭欲からでた偽物であったこと，従ってゾ ータンベールがバグダード写本の中に再発見したガランのアラジンもサッバーグがフラ ンス語からアラビア語に再翻訳したもので, 同様のことがシャヴィと称するシリア人司 祭によるもら一つのシリア伝来版にも言えること，そしてさらに驚くべきことに，マク ドナルドが再発見したアリ・ババの写本も, フランスの碩学ドゥ・サシーの弟子の一人 で後にエジプトに商人として定住したジャン・ワルシーなる人物がフランス語からやは りアラビア語に再翻訳したものであることが判明した。彼の説に従えば, 我々がアラビ アン・ナイトと聞いて最初に思い浮かべるアラジンとアリ・ババの物語のアラビア語原 典がいまだ発見されていないことになる。この原典探索の迷宮を抜け出すためには，い ま一度アラビアン・ナイトの写本の性格について考光てみる必要がある。

マフディーはギリシャ・ラテンの古典文献の写本を校訂する方法をそのまま使って原 テキストを再構成したのであるが，校訂作業に関わる理論的或は技術的問題はさて怙き， アラビアン・ナイトが文学的に高く評価されなかった存在であり, 口承性の高い物語群 であったことを考慮するならば，以下のような問題点が指摘できる。第一に文学的価值 の高い古典文学の場合とは異なり, アラビアン・ナイトの場合, 筆記者が十分注意して 写字したとは考兄られないこと，第二に本来読及物ではなくプロの語り手が暗記用にメ モした写本であること，第三に語り手がメモする場合も，筆記者が写本を写字する場合 む，自分の好みと聞き手や読み手の要望に応じて物語を粉飾したと考兄られることであ る。

さらに, アラビアン・ナイトのようにロ頭による伝承が重要な意味を持つ文学テキス トの場合は, 口頭と文字の伝承の相違と相互の影響を考慮しなければならない。例えば， シリア写本群よりエジプト写本群が新しいと必ずしも言光ないのは, エジプト写本の中 に直接シリア写本より古い写本から筆写されたものがある可能性だけでなく, 別系統の 古い口頭による伝承を残す物語が筆記された可能性もあるからである。無名の人びとの 手で徐々に形成されてきた複雑な歴史を持つアラビアン・ナイトの原典がどれかという 問題は，どの段階の物語群をるって最初の統一的物語集とするかという問題であり，シ リア版ともエジプト版とも言光るし，各時代のアラビアン・ナイトがあったとも言える。 この問題に答えるためには，中東諸国に残存する写本群と個々の物語の内容に関するさ らなる比較研究が必要である。 


\section{IV. 物語の変身}

第3 章 Oceans of Stories〔物語の大海】では, アラビアン・ナイトの物語の来歴 を探る比較研究のために，類似した物語を含むインド，ギリシャ・ラテン，古代中近東， イラン等の書物，さらにアラブ古典文学や大衆文学，ガラン版以前にヨーロッパで流布 していた物語集等が，その類似性と影響関係の観点から検討される。

アラビアン・ナイトを含めた民間説話の起源がインドにあるとする19世紀の説は，フ ィンランド学派達を中心に発展してきた科学的研究によって, 過去のものとなったが, 各物語の起源や影響関係を確定することは単純ではなく, さらに多くの基礎的作業が必 要である。物語の筋や構成要素が類似している場合, それらが独立して成立したのか, 何らかの借用関係があるのかを判断することは難しく, 口伝と書伝といら伝承経路を考 慮するならば問題はさらに複雑になる。例兄ば，ガラン以前に書かれた『カンタベリー 物語』等のヨーロッパの物語集とアラビアン・ナイトには多くの類似点があるが，ヨー ロッパ世界とアラブ世界ですでに流布していた物語が相互に独立して収められた可能性 もある。これまでのアラビアン・ナイトの研究は, とれに高い文学的価值を認めなかっ たアラブ世界ではなく，ペローの童話集の成功に刺激されたガランの翻訳とともにヨー ロッパを中心としてその歴史的関心のままになされてきた。

「フランス語への早い時期に和ける翻訳と18世紀のヨーロッパ人の嗜好に合致したこ とが，この独特の物語集が世に埋もれ，やがて忘れ去られていくことから救った」とい ら著者の言葉は，必ずしもヨーロッパ文明に属する者の傲慢さによるものではない。確 かに，インドに源を発した物語が中東を経てヨーロッパに入ったとする説の背景には， 印欧語系の古代インドとヨーロッパを結び付け，古代文明がイスラム文明を経て西洋文 明に継承されたとする文明史観がある。また19世紀のアラビアン・ナイト写本探索と原 典確立への情熱の背景には, 理解不能のアラブ・イスラム世界といら「オリェント」に 関する百科全書的知識を綜合し，それを「科学」的枠組みの中で了解可能にしょうとい う知的欲望と, その欲望を実現させるための基礎的作業として従来のものより正確な資 料を「科学」的に確定しなけ机ばならないといら学問的反省があった。さらに，アラビ アン・ナイトといら「オリエント」の民鼻文学への19世紀ヨーロッパに掠ける熱病にも 似た異常な関心の高まりの背景には，ドイッのグリム兄弟による童話集やドイッ語辞典 の編篹に代表される思想的赹勢があった。宗教改革の結果, 「聖」としてのカトリック 的中心至上主義が打破され，「俗」としてのプロテスタント的地域・土着主義が強力に 台頭し，これが原動力となってナショナリズムが勃興していく中で，「民族」といら概 念に具体的存在感を与光るために地域土着の民俗文化（フォークロア）としての民話が 収集・研究され，「民族」語を科学するための言語学（フィロロジー）が発展したので 
ある。

ナショナリズムはヨーロッパに拈いて地域民衆の文学や言語の研究, つまり民話研究 や方言学の隆盛をもたらしたが，一方アラブ世界に拈いては全く反対の様相を呈した。

「アラブ民族」主義というヨーロッパ列強勢力に対抗するために産み出された一種のナ ショナリズム思想に秥いては，アラブの統一原理としての正則アラビア語とそれによる 古典文学こそが重要なのであり，逆にヨーロッパによるアラブ世界の分割支配を正当化 するよらな地域文化の称揚につながる民話や方言の研究は，まさしく百害あって一利も ない存在であった。このようなアラブ知識人の態度は, 古典アラビア語とその文学にの み文学的価值を認めるといら従来からのアラブ文学者達の考方方とあいまって，アラブ 人研究者による民話研究やアラビア語方言研究を遅らせる要因となった。ぬた，歴史の 皮肉な逆説と言えるかも知れないが，民話といら民衆の意識に根ざした散文文学を文学 的に昇華できなかったアラブ世界では，現代的意味の小説というジャンルがやっと19世 紀後半になってヨーロッパからの輸入文化として登場したのに対して, ヨーロッパに拉 いては，まさしくアラビアン・ナイト等の東洋の物語への関心を土台として近代小説が 産声をあげたのである。このような生産的関係が，アラビアン・ナイトを産み出したア ラブ世界と，中国，日本，東南アジア諸国をはじめとする東洋の文化との間にあったか どらかについてはもらろん，本書で扱われない東洋の民話とアラビアン・ナイトの関係 について今後の研究が待たれる。

\section{V. 言葉の魔術師}

第 4 章 The Storyteller's Craft〔語り手の技巧〕では, 職業的専門家としての語り 手に関する研究成果が紹介される。現代のストーリーテラーたる小説家の起源を中世の プロの語り手に求めることには議論の余地があるとしても，特に中世のアラブ世界に拉 ける彼らの実態はまだよくわかっておらず，今後の研究が必要な分野である。これまで の知見によれば，中東に括けるプロの語り手の起源は，宗教界と俗世間の二つに求めら れる。前者には，モスクでフトゥバを行ったハティーブと，宗教的物語を能くしたクッ サース（カーッス）が挙げられる。預言者ムハンマドととの教光，初期の征服史等を様 々に粉飾しながらもわかりやすく語ったクッサースも，初期にはイスラム教を拡める上 で重要な貢献をしたが，宗教学者達によって宗教的物語の正統性が権威付けられたり， 逆に否定されたりしていくに連れて，彼らの語る物語は正統を外れたいかがわしいるの と見なされるようになり，やがて彼ら自身も社会的身分の低い，金儲けに語りをする輩 と見なされるよらになった。今一つの語り手の起源は民衆演劇にある。ギリシャの古典 時代から盛んだった笑劇の伝統は，イスラム時代に入ってすたれたと従来は考えられて 
いたが，最近の研究によると，民衆文化に関する史料があまり残っていないだけで，実 際には社会の様々な階層や職業の人をまねた，マイムと呼ばれる笑劇は，中世のアラブ 世界に扮いても活況を呈していたようである。事実, 現代アラビア語で物語一般を意味 するとカーヤといら言葉も元々はマイム劇の物語を指していたようで，14世紀の初め頃 からマイム劇に代わってプロの語り手が人気を博し始めるとともに, 現代語に近い内容 を意味するようになったらしい。

アラブの征服によりギリシャの学問は翻訳所等の公式な機関を通じてイスラム文化に 吸収されていったが，マイム劇のような民衆レベルの文化的伝統がどのように扱われた のか，それに関わる職能集団がどのような運命をたどったのかといら問題は, 極めて興 味深いテーマである。少なくともアラビアン・ナイトのギリシャ古典に類する物語群は, 彼らの手によって伝光られた可能性もある。プロの語り手の身分はかなり低かったよう で, 手品師等の大道芸人と同類と考光られて特り, 実際語り手達の仕事場は大道芸人達 がたむるする通りであった。ただし，16世紀頃からコーヒーが流行するよらになると， 多くの語り手達はコーヒー八ウスをその根城とするようになっていった。また, 結婚式 などのために金持ちの私邸に呼ばれたり，技巧にすぐれた者の中にはまれに宮廷に召し かかえられた者もいたが，彼らの大部分は，伝記資料はもちろん，名前さ元も後世に残 さなかった市井の人びとであった。彼らがどのような生活をし，どれくらいの稼ぎがあ り，またどのように語りの技巧を研き，どのように伝えていったのかといった事柄はま だよくわかっていない。ただし，断片的な見聞録によれば，物語が全くの口伝で暗記に よって語られたのではなく, 実際には, メモ程度であったか正確なテキストであったか はよくわからないが，書かれたものを基に語られたようである。これには，口伝劣の物 語よりも後世に伝えるべく文字化された物語の方が，内容的に優れているとする文化的 背景があったようだ。

ここで問題となるのは，アラビアン・ナイトを含めたプロの語り手による物語群の口 承性である。拈とらく基本的には口伝によって語りの内容と技法が継承されながらも, その量もあって, 語りの補助として書かれたテキストも存在したといらことは, 純粋の 口頭伝承でもなく文字文学でもないという, 著者の言葉を借りれば，「文化的両義性」 を持った存在であったことを意味し，このことはとりもな怙さず，アラビアン・ナイト をはじめとする語り物が，口承文学としての特徴だけでなく, 論理的明晰性といら文学 的審美の眼を通して洗練されてきた文学であることを意味する。従って, 口承文学とし ての民話研究に括いて蓄積されてきた知見と方法論の多くは, 必ずしもアラビアン・ナ イト研究にふさわしいとは言えない。しかし, アラビアン・ナイト研究は, 純粋な口承 芸術である詩の研究と同列に扱らこともできないし，かといって，朗唱によって聴衆の 
高い評価を得てきたコーランのような作品が古典文学の中にもある点を考慮に入れたと しても，常に書くことを前提とした古典文学の研究と同列に扱うこともできない。

また，民話としての口承性は，アラビアン・ナイトをはじめとする民衆文学に高い評 価が与兄られなかった理由とも関連する。フラーファ〔＝おちとぎ話〕と呼ばれる民話は 本来女性によって家庭で語られる，抒九な子供向けのものであり，また，物語を語った り聴いたりすること自体が時間の無䭾で誉められるべき行為ではないと考兄られていた ため，サマル[二夜とぎ]とも呼ばれるよらに，一日の仕事の終わった夜，或は一年の 休閑期に語られることが多かった。このように語り物文学, ひいては快楽につながる㛏 楽全体に対する社会的価值観が，先述したよらな，クッサースといらいかがわしい説教 師やマイム劇といら外来文化を継承した拈とらく外来の芝居人（実際，ニダヤ人やジプ シーが多かった）のような身分の低い者を起源としてプロの語り手達の職業集団が形成 されてきたという社会史的事実とあいまって，アラビアン・ナイトに対する評価を決定 したのである。このような社会的評価は現代のテレビへの評価に通じるものがあるが， それ以上に，両者の社会的機能の類似性に気づく。語り手達の語る物語や即興の話が， 娛楽としてのみ機能していたのではなく，過去の歴史を伝え，異国の風物を教え，不思 議な出来事を解き明かすという，まさしく現在のテレビがになっている情報伝達の機能 を持っていたのである。その意味で，テレビ等の近代的メディアが出現するにつれ，ア ラビアン・ナイトの語り手がいなくなり，語られることもなくなったのは，歴史の必然 であると言える。とにかく，アラブ世界だけでなくトルコやイランの語り手に関する研 究はもちろん，本来の口承文芸としての民話がどのように地域社会や家庭で語られてき たのか関する研究が必要である。

\section{VI. アラビアン・ナイトの「都市性」}

第 5 章 Street Entertainments【街の歓楽】では, 中世アラブ社会の民衆像を探るた めの社会史的資料としてアラビアン・ナイトを利用することを提言し，アラビアン・ナ イトが語るバグダードやカイロの街の風景や，奇術師をはじめとする語り手の商売上の ライバル達の姿を描く。ヨーロッパの社会史的研究と違い史料的制限もあり, アラブ・ イスラム世界の社会史的研究は，ゲニザ文書を利用したゴイテインの一連の研究を除い てあまり進展していないのが実状である。アラビアン・ナイトは豊かな成果を約束して くれる社会史的資料なのであるが，著者も指摘しているように，アラビアン・ナイトは 都市に生活する人びとが産み出した作品であり，たと主様の宮殿が語られても，それ は一度も宮殿に足を踏みいれたことのない庶民の想像の産物であり，登場する農民や遊 牧民も都市民の色眼鏡で見た姿を反映したるのである。都市といら空間こそが，語りの 
場であり，語られる場でもある。司馬遼太郎氏は都会の文明的特性を「数奇」といら言 葉で表現したが，まさしくアラビアン・ナイトの登場人物の運命の数奇は，都会の数奇 であり，日タが日常的平凡の連続である農村や遊牧社会のものではない。

\section{VII． 泥棒とセックスと嘘と}

第 6 章 Low Life〔庶民の生活〕では，犯罪者や犯罪組織などの裏の社会が，また第 7 章 Sexual Fictions [性的作り話]では, 性生活や男女関係に関する庶民の姿が描写 される。内容の紹介は紙数の都合上割愛するとして, 中世アラブ社会に生きた庶民の犯 罪観や女性観等の価值観を明らかにするための資料としてアラビアン・ナイトを利用す ることに全く異存はない。しかし，次の二つの事実を理解して和く必要がある。まず， アラビアン・ナイトの描く社会があくまで虚構であり，娛楽のためだけでなく社会教育 として実際には起こり得ない理想像的な内容が語られる場合もあったといら事実である。 次に, アラビアン・ナイトがフェミニスト論者と反フェミニスト論者の両方にそれぞれ の説の拠り所として引用されていることからもわかるように, 物語の内容は雑多であり， 特定の方向性を持って扱われる汪ど一様ではないという事実である。また，男装や女装 のように，必ずしる現実社会の反映ではなく，語りの文学的手法として使われている場 合もあることにも留意すべきである。

\section{VIII.「科学」的パラダイム}

第 8 章 The Universe of Marvels [不思議の宇宙]では, アラビアン・ナイトの中 の不可思議な出来事や物体について，その文化的意味之聴衆心理との関係が説明される。 西洋科学の洗練を受けた我々現代人の目には全くありえないことのように見觉る魔法使 いの魔法や空飛ぶ䋐逑のような秘密兵器，奇態な異国の住民と風習，ジニーのような妖 怪や怪物，これら全てが，語りの場にいた当時の普通の人びとの知識や考方方を反映し たものであり，まさしく彼らの「科学」的知識を背景に紡がれたものの語りなのである。 占星術や土占い, 人相学などの知識は, 当時の最先端の「科学」として, 世界の一見複 雑で雑多な現象の背後にある原理を読み解くためのパラダイムであり, 表層的事実とそ の技法を用いて，常人にはとうてい知り兄ない深層の秘密を「演繹」するための秘術で あった。魔術師は言語の論理に内包された神秘と文字の魔力で様々な現象を操り, 泥棒 は土占いを宝探しに応用し，奴赨商人は商品たる奴隷の鑑定に人相学を用いた。

著者の指摘にもあるように，不思議の宇宙を描くアラビアン・ナイトの物語は，「科 学」的虚構としての現代のS F 小説に相当し, その起源と考兄てもいいだろう。言葉自 体の魔力による魔法使いに似て，ただ「語り」の技法の魔力を使うのだが，語り手は突 
然聴衆を日常の向こうにある不思議の世界に連れ込み，その神秘をかいまみせ，そして 再び聴衆の好奇心を満足させた後に日常に連れ戻す。その過程で，子供は空想の世界で 想像力を養い，大人は日常を別の視点から見る。このような語りの心理的効果は，日常 性との断絶によって精神を慰撫するといら点で，宗教の持つ効果と似ている。ただし， アラビアン・ナイトが，その内容に抒いて「科学」小説的であり，その心理的効果に扮 いて宗教的であるとしても，以下の点を十分認識して拉く必要がある。つまり，語られ る場面が過去指向であること, ニートピア的発想が少ないこと，さらには魔女などの扱 いでイスラム教的世界観の影響が顕著であること，またさらには，登場人物の行動を予 言したり規定する夢占いや運命に関する記述が同様にイスラム教的世界観の影響を受け ているだけでなく，物語を進行させる上での経済性や心理的効果を得るための語りの技 法として使われていることなどである。

\section{IX. 物語の文法}

第 9 章 Formal Readings [形式的解読]では, 物語をその内容ではなく形式の面か ら分析するために，口承文学研究で展開されてきた議論を紹介し，それをアラビアン・ ナイトに応用する際に生じる様々な問題点を論じる。アラビアン・ナイトにも世界の民 話に共通する形式的特徴がみられるが，口承文芸でもあり文字文学でもあるといら曖昧 性或は両義性のために, アラビアン・ナイトは文学研究や民話研究のまじめな対象にな ることが少なかった。文学研究者は, 東洋的エキゾチズムに満ちてはいるが文学的には 粗野な作品と見なした。グリム兄弟を先駆者とする民話研究者も，特にドイッにおいて は，民話は基本的に全て古代アーリア神話が崩れたものであるとするマックス・ミュー ラーの説の影響を受けて, 物語の起源にのみ研究の関心を向けた。フィンランド学派の 歴史地理的分析から，構造主義的分析で時代を画したウラジミール・プロップと，その 後継者たるグレマスやブレモン, アラン・ダンダスの業績, またフロイト学派やニング 学派の心理学的分析などへと至る研究史については割愛し, ここではそれぞれの学派の アラビアン・ナイト研究への貢献とその可能性について触れる。

アンティ・アアルネとスティス・トンプソンの『民話のタイプ』及び後者の『モティ ーフ・インデックス』は民話を分類・整理し，研究するための基本的文献であるが，こ れに準拠したアラブ民話の分類目録はもちろん，アラビアン・ナイトの物語群に関する 分析もまだない。現在の民話タイプ・モティーフの分類には, 口承文学を主な対象とし ていること，西洋の民話の枠組みであること，分類自体にも理論的欠陥があること等の 幾つかの問題点があるが, アラブ民話の目録化は急務である。アラン゙アン・ナイトにつ いては，ニキタ・エリセーエフのテーマ別分類があるが，これはクリステンセンの極め 
て不十分な分類基準に基づくものであり, 当該の物語や出来事などがどこにあったかを 確認する作業には有用だが, 物語の理解に役立つものではない。プロップの形態論的民 話分析の方法をアラビフン・ナイトに適用したのは, アンドレ・ミケルの一連の研究で ある。しかし，アラビアン・ナイトの物語の構成が複雑であるために必ずしも満足のい く結果が得られているわけではない。プロップ理論を発展させ，民話の文法をめざした トドロフの民話理論を基にさらに言語学の生成文法の考え方を援用したのが，エジプト 人学者ガズールである。プロップ理論と口承詩研究で展開されたパリーとロードの口承 定型理論に着目したのが，最近のデヴィド・ピノルトの研究である。生成文法の名詞や 動詞のように物語の構成要素を扱えるかどらか，また口承詩の単語や句と同じょうに最 小の構成物語を扱えるかどらかは，議論の余地のあるところである。ミア・ゲルハルト の研究は特定の方法論によるものでもなく, 形態論的分析を目指したものでもないが, 物語形式の理解にとって示唆に富む。パトリス・クソネの一連の研究は個々の物語を時 代的に位置付け，社会的・思想的背景を明らかにする極めて貴重な成果である。

民話をはじめとする口承文学の比較・対照による形式的研究は, 理論偏重になったり, 文化特有の部分を取り除いた物語の骨格のみを扱ら無味乾燥なるのになりがちだが，民 話の物語に関する我々の素朴な疑問，例党ば，物語はどこでどのようにしてなぜ産まれ るのか，またよく似た物語があるのはなぜか，似たり受け継がれたりするのは物語の一 部だけなのか全部なのかそれともモティーフなのか，どのような物語が人びとの記憶に 残りやすく代々継承されていくのか，その生存競争の過程で物語はどのような変容を受 けるのか，といった疑問に対する有効な手法である。例觉ば，枠物語の形式については， 幾つかの相互に脈絡のない物語を一緒に慗げて話すための語りの技法として発達したと 考光たり，次々に物語を入れ箱のように囲い达むことで聞き手に日常と非日常の境界が 無くなり自身も物語の枠の中に入ってしまったかのような錯覚を起こさせる心理的効果 があると考光たり，またこれを現代文学のように精神の不安定な流れを反映させる技法 として高く評価したりした。しかし，民話の形式的特徵といら観点から考兵るならば， 登場人物の性格描写が不可欠である近代小説とは異なり, 民話では登場人物の性格がそ の行動によってのみ聞き手に語られるのであり，新たな人物が登場する度に自らの物語 を語るのは, その登場人物の性格設定を行う目的に沿ったものであり, 口承文学の形式 的要請から発達したとも考兄られる。

\section{X. アラビアン・ナイト症候群から文明へ}

第10章 Children of the Nights〔ナイトの子供達】では, ヨーロッパ文学への影響を 扱ら。アラビアン・ナイトの西洋文学への影響を同じくオリエントの物語集たる聖書の 
影響に例えているが，この例えは必ずしも誇張ではない。個々の作家や作品に関する議 論は本書に譲るが，アラビアン・ナイトがその内容や形式において直接的・間接的に与 えた影響は多岐にわたり，特に近代小説の成立過程で果たした役割は無視できない。も ちろん，アラビアン・ナイト症候群とでも呼べる文学的流行は，ガラン訳の出現という 偶然や政治的関心による東洋趣味の興隆に伴らものだが，特にイギリスで顕著なように， 古典文学の正統性への挑戦といら意味でのゴシック的なものへの関心の傾斜と軌を一に していること, 啓蒙思想や科学的合理精神への反動としての不可思議で非「科学」的世 界への憧景的動機があること，現実のオリエントの文化への関心といらよりはむしろ哲 学的思弁のためのいわば日常性を超越した現実感の希薄な形而上的舞台としてオリエ ントが選択される場合もあることの以上三点をここでは指摘して拉く。従って，古典的 或は中世的なくびきから逃れて近代的自我を語るための文学的手法が確立され，また近 代科学のパラダイムが暴力的に浸透し，また空想的オリエントが支配し開発すべきもの として現実の政治・経済的関心の対象となってくると，アラビアン・ナイトが子供向け の非科学的な異国の昔話と位置付けられるようになったのは歷史の必然と言える。語り の文化として中世のアラブ世界でアラビアン・ナイトが果たした役割や，近代小説が出 現する上でアラビアン・ナイトがヨーロッパ文学で果たした役割は終ったのであり，今 後学問的により優れたアラビアン・ナイトの原典訳が出現したとしても，18・19世紀の ヨーロッパで見られたような文化的創造力をもはや期待することはできない。しかし， それでアラビアン・ナイトの影響力が全く失したわけでもなければ，その学問的研究が 不用になったわけでもない。かつて詩人ワーズワースが子供の頃のアラビアン・ナイト との出会いを詩作の糧とし，考古学者レヤードがホメロスを読んだシュリーマンの如く 子供の頃聴いた黄銅城の話に魅せられて多くの考古学的発見をなしたように, アラジン やアリ・ババなどの個々の物語は，ただ，ディズニー映画『アラジン』を見ればわかる ように，現実の中東アラブ世界とは無縁の普遍的テーマを报ら世界童話の一つとしてで はあるが，世界中の子供達の心に何かを語り続けるだろう。

アラビアン・ナイトへの熱狂から醒めた現代こそが，そして近代的自我の確立のみに 専心し，「語り手(ストーリーテラー)」を失ってしまった現代こそが, 純粋に学問的 関心からアラビアン・ナイト研究を行ら最良の時期だろら。このよらなアラビアン・ナ イトの相対化作業にとって，前嶋・池田訳『アラビアン・ナイト』を得た現代日本の研 究者は最も恵まれていると言光るが，原典自体の性格も含めて，同訳書を決定版として 正典化するのではなく，20世紀の日本語版アラビアン・ナイトとして相対的にその学問 的価值を判断しなければならない。著者も言ら。アラビアン・ナイトの登場人物が物語 ることで自らの生命を救ったよらに, 現実の世界に括いても, 物語ととの知恵が個人と 
その属する社会を生き延びさせてきた。そして，現代人もその恩恵を受けた，物語の継 承者なのである。

注

（1）本研究は，文部省科学研究費補助金・一般研究C（平成 $5 \cdot 6$ 年度）「民話モテ ィーフ・データベースの試作と物語構造の計量的分析手法の開発」（課題番号058010 71 : 研究代表者・東京外国語大学アジア・アフリカ言語文化研究所助教授・小田淳 一) の成果の一部である。また，本研究のための海外での資料調査は，平成 6 年度の 国際交流基金の助成による。記して，感謝したい。

（2）現在，筆者の属する研究所では，モティーフ・インデックスの改良を行らため, 民話資料及び民話目録のデータベース化作業を精力的にしている[注(1)参照】。 た，同研究所では，ロンドン大学 SOAS と共同で，中東民話の Oral Archive 設立 を計画中である。尚，アラブ民話のモティーフ分類については，エジプトの Hasan El-Shamy による目録が近々出版予定である。

〔本稿中の研究者とその研究書の具体的な名称については, 紙数の都合上, アーウィ ンの同書を参照願いたい。今後の読者のために誤値等を指摘しておく。26頁11行 : 誤 Thomas Wright $>$ 正 William Wright, 33頁23行: 誤 It $>$ 正 It is。また, 欧米の この種の一般向けの本においてはよくみられることだが，やはり読者の便宜を考㝋て， アラビア語の転写は長母音を記したほうが望ましい。」 